\title{
ARISTOTELÉS O POVAZE A POHYBU NEBESKÉ SFÉRY I Nebe jako tělesná podstata
}

\section{Karel Thein}

V celku Aristotelova díla zaujímají první dvě knihy spisu $O$ nebi notoricky nejasné místo. Nejde jen o spory ohledně toho, zda patří do rámce zkoumání „,celého kosmu“, či pouze vykládají první z pěti živlů, jejichž povahou a pohybem se toto pojednání úžeji zabývá. ${ }^{1}$ Jde rovněž o možnost či nemožnost sloučit výklad pohybu nebeské sféry, který zde Aristotelés nabízí, s řadou pasáží jiných spisů včetně XII. knihy Metafyziky. Následující studie, rozdělená do dvou částí, ${ }^{2}$ nahlíží tento problém z hlediska pojednání $O$ nebi, jež aplikuje postupy př́rodní filosofie na oblast, která se vymyká přímé zkušenosti a je dostupná jen vzdálenému pozorování. Čím se tato aplikace liší od jiných přírodovědných spisů, je Aristotelovo přesvědčení, že pohybující se nebeská sféra je garancí trvalé struktury světa a jako taková je látkovým, nicméně zcela dokonalým jsoucnem. Tento předpoklad, promítnutý do pojetí samostatně

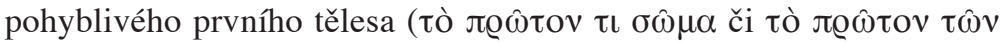

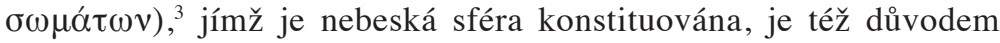

1 První z těchto názorů připisuje Simplikios Alexandru z Afrodisiady (In De Caelo, 11,7-8, vyd. I. L. Heiberg, Berlin 1894). Sám Simplikios se kloní spíše ke druhému čtení. K této otázce a jejímu kontextu viz podrobně T. Kukkonen, On Aristotle's World, in: Oxford Studies in Ancient Philosophy, 46, 2014, str. 311-352. Text De caelo cituji podle vydání D. J. Allana, Oxford 1936. Česky citované pasáže se opírají o často výrazně pozměněný překlad M. Okála in: Aristotelés, $O$ nebi $-O$ vzniku a zániku, Bratislava 1985. V prŕípadě jiných spisů cituji namnoze upravené překlady A. Kř́̌že (jsou-li k dispozici).

2 Druhá část studie vyjde in: Reflexe, 56, 2019.

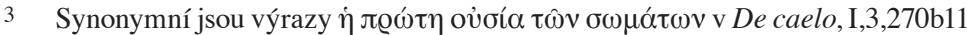

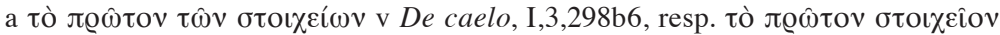

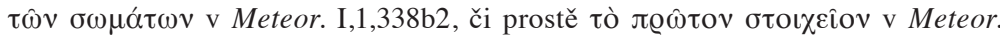

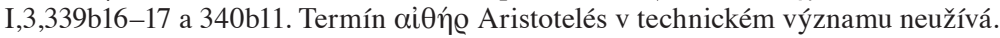
Pojetí látky nebes jako quinta natura či quinta essentia, stejně jako úvahy o její spřízněnosti s konstitucí lidské duše, jsou pozdějšího data. Viz P. Moraux, Quinta Essentia, in: Paulys Realencyclopädie der klassischen Altertumswissenschaft, 
Aristotelova odmítnutí duše světa. Cílem první části této studie je proto připomenout základní rysy Aristotelovy argumentace týkající se nebeského pohybu za současné absence duše, jež by mohla být za tento pohyb odpovědná. Podle následujícího čtení není nepřítomnost duše v aristotelském nebi jen zdánlivá, jak se domnívá řada čtenářo̊. Plyne naopak ze základních premis, z nichž první dvě knihy pojednání $O$ nebi vycházejí, a současně $\mathrm{z}$ pojetí duše $\mathrm{v}$ jiných př́rodovědných spisech.

Bez př́lišného předjímání závěrů, k nimž nás dovede text spisu $O$ nebi, je třeba ihned upřesnit, že odmítnutí duše světa nemusí přímo souviset s tím, že Aristotelův výklad nepřiznává žádnou významnější roli prvnímu nehybnému hybateli, jenž by byl netělesnou příčinou nebeské rotace. Jak uvidíme ve druhé části studie, jediná výslovná zmínka netělesného hybatele v celém pojednání (De caelo, II,6,288b5-6) není spojena s nutností nehybného počátku veškerého pohybu, s nímž jistě pracuje (pokaždé různě) Fyzika VIII a Metafyzika XII. Zjevným důvodem této situace je fakt, že spis $O$ nebi se nezabývá jen formální analýzou pohybu, ale též výkladem jeho - zcela jedinečného - nositele. Tento důvod jen posiluje již zmíněný problém slučitelnosti tohoto výkladu s výklady nebeských pohybů v jiných textech. Tento problém nemohu diskutovat v jeho plném rozsahu. Hlavní důvod odlišnosti spisu O nebi a zejména Metafyziky XII se pokusí načrtnout až závěr celé studie. Jádrem studie je nicméně výklad spisu $O$ nebi I-II s důrazem na předpoklady a důsledky Aristotelova zavedení prvního tělesa. První část studie se proto zaměří na samo zavedení prvního tělesa a na otázku, v jakém smyslu je nebeská sféra oživená. Část druhá nabídne výklad pasáží, jež jsou přímo relevantní pro výsledné napětí mezi pojmem prvního tělesa a motivem prvního nehybného hybatele.

Před vlastním výkladem je nutné vyjasnit jeden metodologický bod. V literatuře se lze setkat s názorem, že nauka obsažená ve spise $O$ nebi odpovídá určitému stadiu Aristotelova filosofického vývoje, které předchází Metafyzice XII či Fyzice VIII. ${ }^{4}$ Toto vývojové čtení však v našem

XXIV, vyd. G. Wissowa, Stuttgart 1964, str. 1171-1263, a Ch. Lefèvre, ,Quinta natura“ et psychologie aristotélicienne, in: Revue philosophique de Louvain, 69, 1971, str. 5-43. Stručná analogie „přirozenosti v pneumatu“ a ,prvku hvězd“, k níž se Aristotelés uchyluje v De gener. animal. II,3,736b37-737a1, je skutečně jen funkční analogií, nikoli látkovým či kauzálním propojením.

4 Variace na základní schéma postupu od mladého Aristotela, jenž věří v oduševnělá nebeská tělesa, přes vyspělejší výklad přirozeného pohybu prvního tělesa v De caelo až po konečnou nauku o prvním hybateli nabízejí Jaeger, von Arnim, Guthrie a Ross. K podobnostem a rozdílům jejich čtení viz H. Cherniss, Aristotle's Criticism of Plato and the Academy, Baltimore 1944, str. 581-602, a stručněji D. W. Graham, The Metaphysics of Motion. Natural Motion in Physics II and Phy- 
případě naráží na zcela základní obtíž. Vývojové čtení je totiž ve svém spekulativním živlu tam, kde běží o vysvětlení rozporných tvrzení týkajících se stejného tématu, zejména pokud jde o Aristotelova tvrzení o podstatě v Kategoriích a Metafyzice VII. Př́ípad spisu $O$ nebi a Metafyziky XII je však jiný proto, že Metafyzika nenabízí žádný alternativní výklad látky, z níž sestává nebeská sféra včetně nebeských těles. Výsledná situace je přesně taková, jak ukazuje již Theofrastova Metafyzika (7,5a21-b7): Aristotelés nepředkládá žádnou uspokojivou a jednotnou teorii, která by sloučila výklad prrípadné vnější příčiny nebeské rotace s výkladem této rotace samotné. Ani v samotném pojednání $O$ nebi ani v Metafyzice XII není navíc jasně vyložen vztah mezi globální rotací nebe a přirozenými pohyby různě se pohybujících sfér planet. Ani tato absence tak není argumentem pro konkrétní dataci našeho pojednání, a už vůbec ne možnou oporou názoru, že spis $O$ nebi je směsí nauk z různých období Aristotelova vývoje. ${ }^{5}$ Je-li tento text svého druhu „směsí“, pak jedině natolik, nakolik si jeho jedinečné téma vynucuje ne vždy hladký průnik premis, s nimiž pracuje aristotelská fyzika, biologie a metafyzika.

\section{Zdůvodnění prvního tělesa}

Patrně nejnápadnějším rysem prvních dvou knih spisu $O$ nebi je aplikace premis a závěrů Fyziky I-IV na oblast nepomíjející podstaty, jejíž vlastnosti nelze ověřit týmž způsobem, jímž lze přímo zkoumat podstaty obývající sublunární sféru. Vlastnosti nebeské sféry lze tematizovat a ověřovat přiměřenou či správně vyváženou ( $\varepsilon v ้ \lambda o \gamma o v)$ argumentací, ${ }^{6}$

sics VIII, in: W. Wians (vyd.), Aristotle's Philosophical Development. Problems and Prospects, Lanham 1996, str. 171-172. Ke standardnímu vývojovému čtení vztahu mezi De caelo a dalšími texty viz dále A. Kosman, Aristotle's Prime Mover, in: M. L. Gill - J. G. Lennox (vyd.), Self-Motion from Aristotle to Newton, Princeton 1994, str. 138, a L. Judson, Heavenly Motion and the Unmoved Mover, in: tamt., str. 155-157.

5 Pro kritiku tohoto názoru viz R. Bolton, Two Standards of Inquiry in Aristotle's De caelo (= Two Standards), in: A. C. Bowen - C. Wildberg (vyd.), New Perspectives on Aristotle's De caelo, Leiden 2009, str. 58. Zároveň je třeba mít na mysli, že postup De caelo I-II je skutečně plný opakování s nejasnými variacemi, nečekaných tvrzení a ne vždy jasných předpokladů. Následující výklad od většiny těchto zlomů a obratů odhlíží.

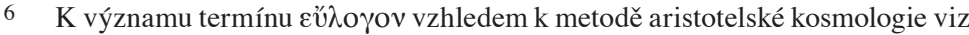
R. Bolton, Two Standards. 
jejímž východiskem je základní geometrická definice tělesa a která navazuje na Fyziku pojetím jednoduchého přirozeného pohybu i odmítnutím existence aktuálně nekonečného tělesa. Postup prvních dvou kapitol celého pojednání, v nichž Aristotelés kombinuje geometrii, přiměřenou argumentaci a fyziku, tak můžeme krajně zjednodušit do deseti následujících kroků:

1. Těleso je dokonalá (čili úplná) rozlehlá entita ( díky tomu, že pouze ono má tři rozměry: nejvyšší počet, $\mathrm{k}$ němuž nelze přidat žádný další rozměr.

2. Svět či kosmos je jakožto těleso též takto dokonalý čili úplný.

3. Přirozeným tělesům náleží schopnost přirozeného pohybu.

4. Existují dva druhy jednoduchého přirozeného pohybu.

5. Pokud jim v tom nic nebrání, jednoduchá tělesa se pohybují jedním z těchto jednoduchých pohybů.

6. Každému jednoduchému tělesu patří pouze jeden druh přirozeného pohybu, přičemž čtyři jednoduchá tělesa ze sublunární sféry charakterizuje přirozený pohyb přímočarý a v tomto smyslu neúplný.

8. Protože však existuje tělesný celek čili svět, jenž není aktuálně nekonečným tělesem, př́močarý pohyb čtyř jednoduchých, nikoli nekonečných těles musí mít nějakou mez.

9. Tato mez je nutně uskutečňována jako jiný jednoduchý pohyb, jenž je kruhový a v tomto smyslu úplný.

10. Tomuto druhu pohybu musí odpovídat jednoduché těleso, které ho vykonává: toto těleso se tedy přirozeně pohybuje v kruhu a svým pohybem obkružuje všechna ostatní jednoduchá tělesa (a tedy i vše, co je z nich složeno).

I takto zjednodušený přehled jasně ukazuje, že - jak Aristotelés brzy přizná - „,některé zde řečené věci byly předpokládány, zatímco jiné dokázány“ (De caelo, I,3,269b17-18). ${ }^{7}$ Naše zjednodušení přitom názorně

7 Postup kapitol I-II je samožrejmě složitější než nabídnuté shrnutí. K argumentační struktuře první kapitoly viz G. Betegh - F. Pedriali - C. Pfeiffer, The Perfection of Bodies. Aristotle's De Caelo I.1, in: Rhizomata, 1, 2013, str. 30-62; k jejím holistickým předpokladům viz M. Matthen - R. J. Hankinson, Aristotle's Universe. Its Form and Matter, in: Synthese, 96, 1993, str. 428-429. K argumentaci kapitoly druhé viz A. Falcon, Corpi e movimenti. Il De caelo di Aristotele e la sua fortuna nel mondo antico, Napoli 2001, str. 95-118. K zavedení prvního tělesa viz též A. Falcon, Aristotle and the Science of Nature. Unity without Uniformity, Cambridge 2005, str. 57-62. 
dokládá postup od geometrické definice tělesa k pohybu jako vlastnímu předmětu fyziky, a následně k nikoli již geometrickému, ale látkovému tělesu, které pohyb vykonává. Všechny vlastnosti prvního tělesa tak budou odvozeny z povahy pohybu, $\mathrm{k}$ němuž je přiřazeno: $\mathrm{z}$ jednoduchého kruhového pohybu, jenž je chápán jako úplný a díky tomu označen za „první prrirozený“ (De caelo, I,3,269a18). Označení tohoto pohybu je pak metonymicky přesunuto na těleso, jež se takto přirozeně pohybuje

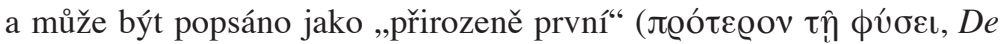
caelo, I,3,269a24).

Již ve druhé kapitole celého spisu tedy sledujeme jemný, ale klíčový posun od ryze geometrické úplnosti těles k odlišně popsatelné dokonalosti, která umožňuje další stupňování: určité těleso je zde popsáno jako „přirozeně první“ na základě určitého druhu pohybu, jemuž je připsáno (a nikoli naopak). V této úvaze přitom Aristotelés nepostupuje od kruhového pohybu k dokonalosti kružnice a poté $\mathrm{k}$ analogické dokonalosti koule, která bude později prohlášena za nutný tvar nebe, a tím celého kosmu (viz De caelo, II,4,286b10-a11). ${ }^{8}$ Nyní, v souvislosti se zavedením prvního přirozeného tělesa, využívá Aristotelés možnosti dát této prvotnosti jasnější hodnotový význam. V závěru celé argumentace, tedy v posledních řádcích druhé kapitoly, je hodnotící hledisko již zcela výslovné: „Na základě všech těchto úvah lze nabýt přesvědčení ( $\pi \iota \sigma \tau \varepsilon v ́ \sigma \varepsilon เ \varepsilon v)$, že je nějaké těleso odlišné od těles zde kolem nás a od nich oddělené

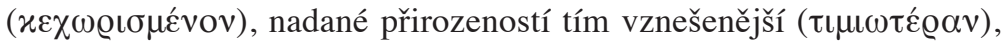
čím je vzdálenější od těles zdejších“ (De caelo, I,2,269b13-16).

Metodologická opatrnost rámuje i tento závěr: uvedli jsme řadu dobrých důvodů, které vedou k oprávněné domněnce, že nějaké těleso odpovídající popisu prvního tělesa existuje. ${ }^{9}$ Mnohem méně opatrná je ovšem formulace dvou vlastností takového tělesa, o nichž se předešlá argumentace nezmiňuje, a které jsou tedy zjevně něčím, $\mathrm{k}$ čemu nás tyto úvahy neprrímo dovedly. První z těchto vlastností je oddělenost, jejíž

8 Toto samostatné zdůvodnění dokonalého tvaru kosmu jako všeobjímajícího celku následuje po výkladu částí nebe a úvaze o tom, proč obsahují nebesa více místních pohybů. K napětí mezi geometrickou dokonalostí nebe a potřebou rozlišovat jeho části viz níže. K otázce, zda je svět jako celek dokonalým ztělesněním geometrického tvaru, viz T. Kouremenos, Aristotle on Geometrical Perfection in the Physical World, in: Mnemosyne, 56, 2003, str. 463-479.

9 Zcela jiné, neoplatónsky exaltované čtení nabízí Simplikios, In De Caelo, 55,8-10: Aristotelova argumentace je zde podložena zvláštním druhem důvěry, jež

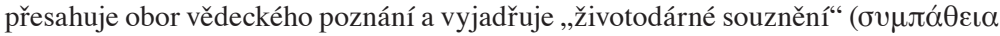

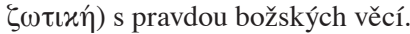


přesný význam není zde ani jinde vysvětlen. Vzhledem ke všemu, co se v pokračování spisu dozvíme o pěti živlech a rozdělení světa na dvě látkově zcela odlišné oblasti, lze přesto s jistotou tvrdit, že „oddělenost“ neoznačuje absenci fyzikálního kontaktu, ${ }^{10}$ ale nesmíšenost prvního tělesa s jinou látkou, a tím také fakt, že toto těleso nevstupuje do procesu vzájemné proměny ostatních čtyř prvků. Jedná se tedy o místní oddělenost prvního tělesa jako zvláštního druhu podstaty. V tomto ohledu máme co činit se stejným rozlišením dvou druhů přirozené pohyblivé podstaty, které nabízí první kapitola Metafyziky XII (a k němuž se vrátí celkový závěr této studie): nesmíšený a věčný druh se liší od druhu, jehož partikulární instance (zvîrata a rostliny složené ze čtyř živlů) jsou pomíjivé (Met. XII,1,1069a30-33).

Právě z tohoto rozlišení je ovšem jasné, že tvrzení o rostoucí vznešenosti prvního tělesa spolu se vzdáleností od smíšených těles kolem nás musí být založeno zcela jiným způsobem. Vzato doslovně, toto tvrzení promítá různou hodnotu do různých částí nebe, což je v jasném napětí s opakovaným důrazem na stejnorodost nebeské sféry a neustálou rotaci všech jejích částí. Aristotelovo hodnotové nadřazení nejvyšší první sféry čili sféry stálic je ovšem zcela jasné a důrazné. ${ }^{11}$ Jeho nejjasnějším projevem je výklad různých nebeských pohybů v kapitole II,12, jejímž východiskem je opakované upozornění na naši vzdálenost od jevů, které se zde snažíme vysvětlit. Pro překonání této nevýhody pak Aristotelés podniká myšlenkový experiment, jenž vychází z pomyslné analogie mezi hvězdami a smrtelnými bytostmi a předpokládá hierarchii různě dokonalých způsobů života. Sféra stálic se ocitá na vrcholu této hierarchie proto, že svého cíle dosahuje jednou činností: jedním pohybem, jenž však hýbe

10 Obě sféry se dotýkají, čímž dochází k tření; viz De caelo, II,7,289a19-32, a Meteor. I,3,341a17-22. K této druhé pasáži viz M. Wilson, Structure and Method in Aristotle's Meteorologica. A More Disorderly Nature, Cambridge 2013, str. 48-50.

11 Pro barvitý popis tohoto rozlišení viz Simplikios, In De Caelo, 490,5-17. Simplikios též zdůrazňuje Aristotelovu polemiku s pythagorejským názorem, že

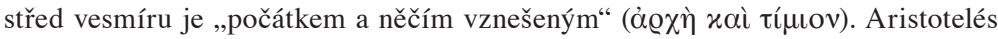
ukazuje, proč je střed v místním významu spíše poslední, než aby byl počátkem: „Střed je totiž tím, co je ohraničené ( $\tau o ̀$ ò ı`ó $\mu \varepsilon v o v)$, zatímco tím, co ohraničuje, je

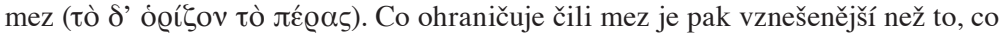

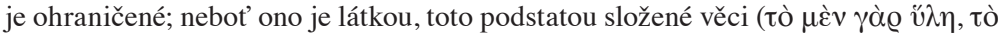

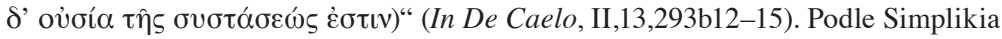
(In De caelo, 514,16-18) souzní toto tvrzení s názorem, že sféra stálic je „počátkem bytí kosmu“, jenž „unáší ostatní sféry a obepíná celou tělesnou přirozenost“ (In De caelo, 514,16-18). Simplikios využívá též pasáží z Fyziky VIII, které mu umožňují tvrdit, že sféra stálic je bližší a ,příbuznějšî‘ prvnímu hybateli. 
mnoha hvězdami a v tomto smyslu „dalece převyšuje“ sféry planet (De caelo, II,12,292b28-30). ${ }^{12}$ Hodnotící rozměr zde neplyne z odlišnosti druhů pohybu, jež umožnila nadřadit celou nebeskou sféru sublunárnímu světu a označit ji za „božštější“ než složená tělesa a za něco vzhledem k nim prvotního (De caelo, I,2,269a30-31). V samém nebi totiž jiný než kruhový pohyb nenajdeme; principem hodnocení se proto stává přesvědčení, jež předchází i samotné analýze pohybu a podle něhož je jednoduchost dokonalejší než složitost. Od tohoto přesvědčení již není daleko k možnému názoru, že vnější a nejrychleji se pohybující část nebe je nejblíže nehybnému hybateli celého kosmu (Phys. VIII,10,267b6-8). Zda lze ozvěnu tohoto názoru nalézt v liteře pojednání $O$ nebi, je otázka, k níž se vrátí až druhá část této studie.

Než bude totiž možné přikročit k tomuto tématu, je nezbytné zdůraznit další rys připsaný v pojednání $O$ nebi, prvnímu tělesu, jež tvoří a vyplňuje celou nebeskou sféru. Tímto rysem je vnitřní oživenost, odlišující první těleso od ostatních jednoduchých těles, která jsou neoživená (srv. De an. I,5,410b16-411a26). Také oživenost má zřejmý hodnotový rozměr a odpovídá další obecné premise, podle níž jsou živé věci lepší než neživé ${ }^{13}$ Motiv hodnocení hraje důležitou roli i proto, že oživenost prvního tělesa není samostatně definována; je-li jasné, že nemá geometricko-fyzikální základ, je stejně obtížné uplatnit na ni výklad o oživenosti složených těl z pojednání $O$ duši. Protože však žádný jiný výklad oživenosti nebe z Aristotelova pera nemáme, příslušné pasáže i z nich plynoucí problémy zasluhují pečlivou pozornost.

\section{Oživenost prvního tělesa}

Nejrazantnější prohlášení na téma oživenosti nebe a jeho hlavního důsledku nabídne pojednání $O$ nebi ve druhé kapitole své II. knihy: „nebe je oživené a náleží mu počátek pohybu“ (ó $\delta$ ' ov̉ @avòs ع

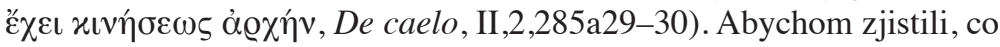
Aristotela opravňuje k tomuto shrnujícímu tvrzení, musíme začít od postupného rozšîrení charakteristiky pohybu prvního tělesa. Již první kniha

12 Ke kapitole II,12 a jejímu myšlenkovému experimentu se podrobněji vrátí druhá část této studie.

13 K důsledkům této premisy pro duší obdařené bytosti v sublunární sféře viz $D e$ gener. animal. II,1,731b24-732a12. K problému oživenosti a duše v nebeské sféře viz následující oddíl. 
přitom vychází z toho, že tento pohyb není jen jednoduše kruhový, ale kruhový přirozeně. Tomuto pohybu tak odpovídá těleso, jež se pohybuje vždy pouze v kruhu, a díky tomu nepodstupuje žádnou ze změn, jež jsou spjaty s jakýmkoli pohybem mezi protivami a vedou dř́ive či později k zániku tělesa, které se pohybuje. Důsledkem této neměnnosti je pak věčnost př́islušného pohybu i tělesa, jež takový pohyb vykonává. Ve druhé až čtvrté kapitole I. knihy věnuje Aristotelés značnou péči formální stránce tohoto argumentu, přičemž však opakovaně připomíná meze našich vědomostí o nebeské sféře (srv. např̀. De caelo, I,3,270a25-35). Nelze-li však skutečně dokázat existenci prvního tělesa a jeho vlastností, lze se alespoň rozumně spolehnout na obecnou zkušenost lidstva, které pozoruje stále stejné nebeské pohyby již tak dlouho, že těleso schopné změny či pohybu z donucení by za tuto dobu jistě zaniklo (srv. De caelo, I,2,269b9-10). Závěr, že „první z těles je věčné (ơuídıvv), nepřibývající ani neubývající, nestárnoucí, neměnné a nepřijímající vnější působení

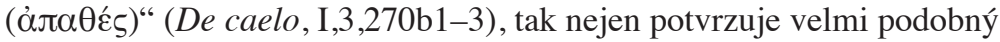
výchozí předpoklad (viz De caelo, I,3,270a12-13), ale skvěle koresponduje se všeobecně přijímaným názorem, že nebeská tělesa jsou božskými bytostmi, jimž náleží neustálý pohyb i jiná než nám běžně známá látka (De caelo, I,3,270b4-25).

Citovaný závěr jasně předjímá dvě další pasáže, v nichž je starší moudrost užita jako více či méně kontrastní pozadí pro Aristotelovy vlastní úvahy. Obě pasáže dále potvrzují, že věčný čili božský status prvního tělesa, stejně jako s ním spjatá oživenost, zůstávají přijatelnými hypotézami, které nelze plně doložit skrze formální argumentaci založenou na druzích přirozeného (a nepřirozeného) pohybu. K prvnímu z těchto textů se vrátíme ve druhé části této studie, nebot' bývá častou oporou čtení, jež promítá do pojednání $O$ nebi prvního nehybného hybatele, a to navzdory Aristotelovu závěru, že první božské entitě se sluší připsat neustálý pohyb, v němž jí nic silnějšího nepohybuje (De caelo, I,9,279a30-b3). Naopak druhá pasáž, z úvodní kapitoly II. knihy, se př́ímo vztahuje k otázce, v jakém smyslu je první těleso oživené.

Příslušný text se vyjadřuje jasněji, pokud jde o zápornou část odpovědi: nebe není oživeno a pohybováno duší. Tento názor je poslední v řadě úctyhodných, avšak zjevně nepřesných mínění o božské povaze nebes a jeho kritika je formulována následovně:

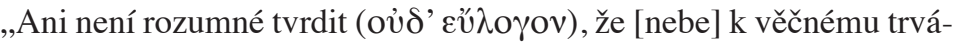
ní nutí duše. Takový život duše by totiž nebyl bez bolesti ani št'astný; vždyt' pohyb provází násilí, pokud [duše] hýbe prvním tělesem, které 
se přirozeně hýbe jinak a nepřetržitě, a [duše] nedochází odpočinku ani vůbec žádného rozumového uspokojení, ani netěží z tělesného uvolnění, jež zakouší duše smrtelných živočichů během jejich spánku; spíše je nucena sdílet Ixiónův osud, věčný a neustálý.“"14

Zvláštností této pasáže je formulace úvahy z hlediska duše, které by bylo k pohybování nebem třeba jen tehdy, kdyby mu udílela jiný než jeho přirozený a původně vykonávaný pohyb, jímž je první těleso definováno. Premisa celé citované úvahy je tedy prostá: duše hýbe tělem tam, kde je třeba docílit pohybu, který by toto tělo nedokázalo bez duše vykonat. Činnost duše není zdvojením jednoduchého přirozeného pohybu, ale ustavující podmínkou přirozených pohybů složených bytostí. Ve světě kolem nás proto nemají duši jednoduchá tělesa, jimž je určitý přirozený pohyb stejně vlastní jako prvnímu tělesu, ale rostliny a živočichové jako bytosti, které jsou směsí jednoduchých těles. Působení duše přitom sahá až k pohybům, jimiž se tato směs utváří: odtud definice duše jako „prvního uskutečnění př́ŕrodního těla, které má v možnosti život“ (De an. II,1,412a27-28). Duše tak nemůže být přítomna v určitém těle bez toho, že by svým působením utvářela jeho stavbu, jejíž činnost od počátku koordinuje a řídí $\mathrm{k}$ určitému přirozenému cíli. Takové řízení první těleso jistě nepotřebuje: pro přítomnost duše ve věčné nebeské sféře, které je původně vlastní jeden jednoduchý pohyb, tak není žádný

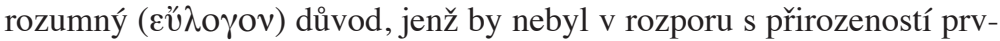
ního tělesa. ${ }^{15}$

Navzdory své jednoznačnosti (a kritice duše světa v pojednání $O$ duši) nebývá tato pasáž pokládána za definitivní odmítnutí nebeské duše. Hlavním textovým důvodem je již citované označení nebe za „oživené“, nebot' výraz č $\mu \psi v \chi 0 \varsigma$ se zdá právě přítomnost duše jasně implikovat. Při bližším pohledu se však potvrzuje, že tato implikace není nutná. Sám spis $O$ duši naznačuje, že „být oživený“ a „mít duši“ v uvedeném smyslu př́ičiny, jež utváří rostlinné či živočišné tělo, není nutně jedno a totéž. Důvodem je širší významové spektrum výrazu ,život“: ,oduševněná by-

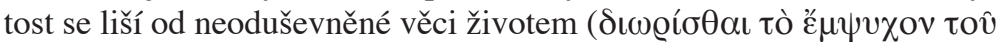

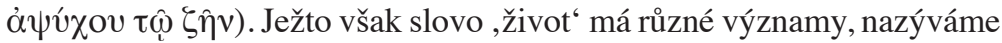

14 Aristotelés, De caelo, II,1,284a27-35. Jako trest za pokus znásilnit Héru je Ixión v Tartaru navěky vpleten do ohnivého, otáčejícího se kola.

15 Citovaná pasáž je též zřejmou kritikou dialogu Timaios a v tomto smyslu doplňuje známější a o něco podrobnější kritiku světové duše ze spisu $O d u s ̌ i$ (viz De an. I,3,406b25-407b12). 


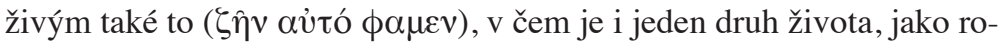
zum, smyslové vnímání, pohyb a klid co do místa, dále pohyb ve smyslu vyživování, ubývání a růst" (De an. II ,2,413a20-25).

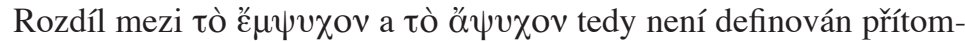
ností duše, která zajišt'uje vyživování, ubývání a růst, smyslové vnímání a rozmanitě orientovaný místní pohyb. Živé bytosti může charakterizovat i činnost omezená na myšlení (případ prvního božského hybatele z Metafyziky XII), nebo činnost spočívající v jednoduchém kruhovém pohybu - což je zjevně případ prvního tělesa čili celé nebeské sféry. Spis $O d u s ̌ i$ se těmito případy nezabývá a většina výskytů slova ě $\mu \psi v \chi o v$ v něm popisuje rostliny a živočichy s duší. Některé pasáže dále dokládají významovou pružnost tohoto slova, jež je používáno i ve smyslu, který na nebeskou sféru, jak ji popisuje spis $O$ nebi, přenést rozhodně nelze. Platí to nejen o tvrzení, že „každá oduševnělá bytost obsahuje teplo“ (De an. II,4,416b29), ale též o nutné přítomnosti hmatu v živočišném těle ( $\sigma \hat{\omega} \mu \alpha$ ह̌ $\mu \psi v \chi O v)$ : hmat totiž předpokládá složenost $\mathrm{z}$ více jednoduchých těles (De an. III,12,434b8-14 a III,13,435a11-14).Z těchto pasáží plyne, že jednoduché těleso nemůže přijímat duši, nebot' $\mathrm{k}$ nutným parametrům těla oživeného duší patří podle spisu $O$ duši složenost, zemitost a vrozené teplo, přičemž ani jedno z toho nebeské první těleso nemá a z definice mít nemůže. Přítomnost duše v pohyblivém těle navíc Aristotelés spojuje se schopností vnímat čili mít smyslové orgány (viz $D e$ an. III,12,434b7-8: ,žádné tělo nemá duši bez smyslového vnímání, leda nepohyblivé" - což je př́ípad rostlin). Chceme-li v této situaci hovořit o duši prvního tělesa nebo o duši jednotlivých nebeských sfér, musíme pozměnit a rozšîrit význam slova „duše“.

Takové rozšrîrení je jistě legitimní a není v komentátorské tradici neznámé. Jasným příkladem je Alexandros z Afrodisiady, jenž dává „duši““ zvláštní význam v souvislosti s výkladem nebeských pohybů a označuje tímto výrazem samu přirozenost prvního tělesa a následně i jednotlivých nebeských sfér: „Přirozenost božského tělesa se neliší od jeho duše, ale je tomu s ní tak, jako s tíží země a lehkostí ohně. " ${ }^{16}$ Duše je tedy v případě

16 Cituje Simplikios, In De Caelo, 380,29-31 (pro celý Alexandrův argument, resp. jeho větší část, viz řádky 380,30-381,2). Výraz „,božské těleso“ odkazuje k celému prvnímu tělesu, v souladu s textem De caelo, II,3,286a8-12, k němuž viz níže. Alexandros rozvíjí své ztotožnění duše a přirozenosti nebe i v jiných textech, konkrétně v Quaestiones, I,40,23-30, a také v pouze arabsky dochovaném spise o kosmu; pro edici a překlad relevantní pasáže viz C. Genequand, Alexander of Aphrodisias. On the Cosmos, Leiden 2000, str. 55, § 20. Zde říká Alexandros jasně, že duše nebeského tělesa není formou, protože takové těleso nepotřebuje různé duší vyvolávané pohy- 
dokonalejšího tělesa pohybujícího se v kruhu totožná s jeho lepší přirozeností a spolu s ní je trvale uskutečněna, na rozdíl od duší z pojednání $O$ duši, jejichž uskutečnění je vázáno na vytváření a udržování vždy jen dočasné tělesné struktury. Což jasně potvrzuje, že duše, o níž zde mluví Alexandros, je v zásadě přejmenování přirozeně kroužícího těla, jehož pohyb je nakonec popsán stejně jako u Aristotela: duše je v první řadě doplněk přívlastku „božský“, který Alexandros od Aristotela přejímá spolu s předpokladem, že co je božské, nemůže být neživé. Alexandra citující Simplikios přitom s tímto čtením nesouhlasí a odmítá ztotožnění duše a přirozenosti s odkazem na jejich zcela různou definici ve Fyzice, respektive spise $O$ duši . Simplikiovo vlastní řešení pak spočívá v návratu

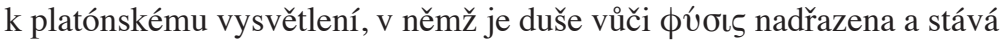
se prvním zdrojem nebeského pohybu, který přirozenost prvního tělesa pouze umožňuje. ${ }^{17}$

Blíže Alexandrovi jsou tak současní interpreti, kteří přripouštějí jak absenci kladné zmínky o nebeské duši z Aristotelovy strany, tak i nejasnost ohledně toho, čím by mohla duše k nebeskému pohybu přispět, ale nakonec navrhují číst Aristotela tak, že přítomnost duše v prvním tělese je nutná k vysvětlení směru nebeského pohybu. ${ }^{18}$ Jedním z důvodů této blízkosti je zřejmě i společný výchozí text (soudě dle místa, kde Alexandra ve svém komentári cituje Simplikios), jímž je metodologicky lehce excentrická kapitola II,2. V tomto textu ovšem nejde o vysvětlení směru nebeského pohybu; tento prostě daný směr je naopak východiskem myšlenkového experimentu, jímž Aristotelés navazuje na pythagorejské tvrzení, že svět jako celek má pravou a levou stranu. Aristotelův postup je přitom aplikací obecnějšího pohledu na strukturu živých bytostí: třírozměrná živá bytost se liší od geometrických i uměle vytvořených těles tím, že její tělo má přirozeně určenou pravou a levou, ale též horní a spodní a rovněž přední a zadní stranu. Toto rozlišení podle trojí osy určuje východisko místního pohybu živého těla

by. K dalším souvislostem Alexandrova čtení viz alespoň I. M. Bodnár, Alexander of Aphrodisias on Celestial Motions, in: Phronesis, 42, 1997, str. 190-205.

17 Viz Simplikios, In De caelo, 381,2-35.

18 Konkrétním autorem, jehož názor zde parafrázuji, je T. K. Johansen, From Plato's Timaeus to Aristotle's De caelo. The Case of the Missing World Soul, in: A. C. Bowen - C. Wildberg (vyd.), New Perspectives on Aristotle's De caelo, str. 9-28 (konkrétně vyjádření ze str. 9, 18 a 20). Příkladem skeptického postoje k předpokladu netělesné nebeské duše ve spise $O$ nebi i v jiných Aristotelových textech je naopak Dougal Blyth, Heavenly Soul in Aristotle, in: Apeiron, 48, 4, 2015, str. 1-39. 
a umožňuje jeho úplný popis, at' už jde o pohyb smrtelných živočichů, nebo oživeného nebe:

„Má-li totiž pravou a levou stranu, musíme nejprve předpokládat, že v sobě má i prvotnější počátky. Stanovili jsme je ve spisech o pohybu živočichů jako to, co je jim přirozeně vlastní; ${ }^{19}$ u některých živočichů jsou totiž všechny takové části zřetelné, např́iklad pravý a levý bok, zatímco u jiných živočichů jen některé a rostliny mají pouze vršek a spodek. Pokud bychom tedy měli nějaká taková určení připsat i nebi, je rozumné ( $\varepsilon u ̛ \lambda o \gamma o v$ ) domnívat se, že co je prvotní u živočichů, je takové i v případě nebe; nebot' každá z oněch tří dvojic je jistým počátkem. Těmito třemi myslím nahoře a dole, přední část a její protiklad a vpravo a vlevo; lze totiž rozumně předpokládat

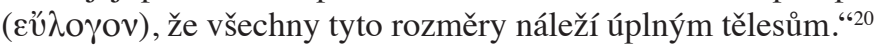

Hledání konkrétních počátků pohybu má tedy v případě nebe metodologický smysl právě na základě premisy, že „nebe je oživené a náleží mu počátek pohybu“ (De caelo, II,2,285a29-30). Postup, jímž Aristotelés promítá rozvrh živočišného pohybu na dokonale kulaté nebe, vychází z kontrafaktické představy toho, jak a odkud by byla bývala začala nebo by se $\mathrm{v}$ případě zastavení obnovila - ve skutečnosti věčná rotace kosmu (viz De caelo, II,2,285b5-7). Místem takového počátku je pomyslná horní pravá část dopředu se točící nebeské klenby; vzhledem k místu, kde my vidíme zleva vycházet hvězdy, musí být tento počátek na pravé straně opačné polokoule, přičemž planetární pohyby mají počátek v symetricky opačné části kosmu. Obýváme tedy dolní levou část světa, zatímco protinožci žijí v části horní a pravé - takto Aristotelés napravuje omyl pythagorejců, kteří „nás“ umist’ují opačně. Celá úvaha, jejíž jednotlivé kroky nemůžeme rozebírat, tak přijímá pythagorejské východisko, ale opravuje závěry, které z něj mají plynout. ${ }^{21}$ Důležité

19 Skutečnou referencí této pasáže i celé kapitoly II,2 je kratší pojednání $O$ chůzi živočichů, nikoli složitější vysvětlení ze spisu $O$ pohybu živočichů, v němž je živočišný pohyb vysvětlován též z hlediska př̀edstavy svého cíle.

20 Aristotelés, De caelo, II,2,284b10-24.

21 Pro podrobnější analýzu celé kapitoly viz J. G. Lennox, De Caelo 2.2 and Its Debt to the De Incessu Animalium, in: A. C. Bowen - C. Wildberg (vyd.), New Perspectives on Aristotle's De caelo, str. 187-214. Oproti tomu, co tvrdí L. Judson, Heavenly Motion and the Unmoved Mover, in: M. L. Gill - J. G. Lennox (vyd.), Self-Motion from Aristotle to Newton, str. 159-161, argumentace kapitoly II,2 nikterak nespoléhá na přítomnost duše či duší v jednotlivých nebeských sférách. Simplikios 
ovšem je, že celá úvaha není skutečným odhalením důvodů, proč se svět točí tímto, a ne opačným směrem, nýbrž ex post sestrojenou argumentací, která prostě vychází z daného směru kosmické rotace a v případě rotace opačné by fungovala stejně dobře, byt's opačným popisem našeho místa a místa protinožců. Řečeno jednoduše, ,vpravo nahoře“ je zde již předem definováno směrem, jímž se svět se stejnou daností točí „dopředu“ - at' se tedy svět točí jakkoli, v rámci této úvahy je to vždy stejně popsaným směrem seshora dolů a zprava doleva. ${ }^{22}$

Kapitola II,2 tak premisu oživenosti světa nedoplňuje skutečnou funkční analogií s pohybem živočichů, v níž by hrála kličcovou roli představa cíle pohybu, za niž je u živočichů odpovědná právě duše onoho typu, který kapitola II,1 nebi upírá. Už sama kontrafaktická povaha celé úvahy přitom potvrzuje, že pouze nebeská sféra skutečně hýbe sama sebou, zatímco sublunární živočichové jsou samopohybu schopni jen v nevlastním smyslu (viz Phys. VIII,2,253a10-11 a VIII,6,259b7-8). Nic podobného živočišné duši tedy kapitola II,2 ke svému argumentačnímu postupu nepotřebuje. V této fázi svého výkladu si Aristotelés vystačí s dále nerozlišeným pojmem oživeného prvního tělesa, jehož povaha i sama existence je postupně vyvozena $z$ hodnotově prvního jednoduchého pohybu. Tento argumentační postup nám o prvním tělese neříká nic z látkového hlediska, tedy z hlediska protikladných vlastností, z nichž se odvozují čtyři jednoduchá tělesa v sublunární sféře. ${ }^{23}$ Již víme, že

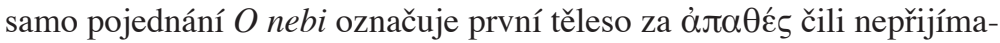
jící vnější (přinejmenším látkové) působení (De caelo, II,2,270b1-3). Jak uvidíme v př́štím oddílu, první těleso lze díky tomu popsat též jako neměnné ( $\dot{\alpha} \mu \varepsilon \tau \alpha \dot{\alpha} \beta \lambda \eta \tau o v)$, přičemž tato záporná vymezení jsou

(In De caelo, 391,33-392,1) nabízí pomocnou vizualizaci: představme si člověka opřeného o osu kosmické rotace s hlavou mířící k jižnímu pólu. Tento člověk se otáčí spolu s celým nebem, přičemž na rozdíl od nás vidí část nebe, kde celý pohyb hypoteticky začíná. Simplikios promítá do jednoho obrazu dvojí odlišnou dokonalost: dokonalost koule jako nejméně rozlišeného geometrického tělesa a dokonalost člověka jako nejvíce rozlišeného živého těla.

22 Což dále potvrzuje kapitola II,5, která se vrací ke směru kosmické rotace. K ní viz více O. Goldin, Cosmic Orientation in Aristotle's De caelo, in: Proceedings of the Boston Area Colloquium in Ancient Philosophy, 26, 2010, str. 91-117.

23 Otázka vztahu mezi čtyřmi vlastnostmi uspořádanými do dvou párů (studené a horké, suché a vlhké) a jednoduchými tělesy je poměrně složitá a nesouvisí přímo $\mathrm{s}$ naším hlavním tématem. Pro přehled problémů, jenž bere v úvahu jak pojednání $O$ vzniku a zániku, tak spis $O$ nebi III-IV, viz T. J. Crowley, De generatione et corruptione 2.3. Does Aristotle Identify the Contraries as Elements?, in: Classical Quarterly, 63, 2013, str. 161-182 (s řadou dalších odkazů). 
formálně dostatečná k tomu, aby šlo o ,jakési těleso božské“ ( $\sigma \omega \hat{\mu} \mu \alpha$

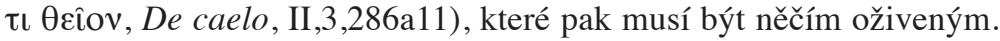
Ani jiné texty nejsou sdílnější, jakkoli stojí za zaznamenání, že Metafyzika (a ne samo pojednání $O$ nebi) označuje první těleso výrazem látka (ư $\lambda \eta)$. V obou př́ípadech jde o stručná vyjádření o zvláštní látce ne-

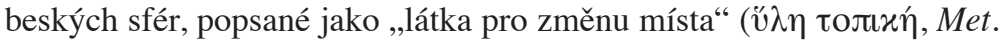
VIII,1,1042b6-8) a „látka nevzniklá, ale pro pohyb odkud a kam“ (oủ

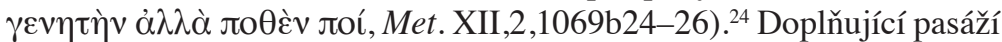
je pak výklad v IX. knize, jenž buduje kontrast mezi látkou v sublunární

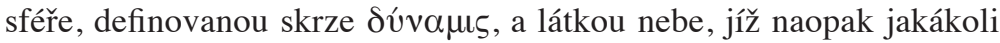

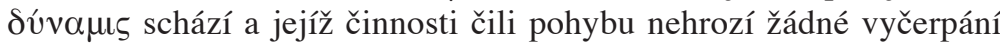
(Met. IX,8,1050b21-29). Ani z tohoto textu ovšem není jasné, jak vůbec mohou v prvním tělese existovat vydělené neviditelné sféry a jimi pohybovaná viditelná tělesa. Vstříným čtením Metafyziky XII,8 lze dospět $\mathrm{k}$ tradičně přijímanému názoru, že sférám náleží jako formálně působící část obdoba duše, která je implicitní zárukou příslušného vydělení. Pojednání $O$ nebi ovšem takové řešení ani nepopírá, ani k němu nevybízí překvapivě ani tehdy, když různost nebeských pohybů tematizuje.

Tato situace patrně souvisí se způsobem, jímž dává spis $O$ nebi přednost výrazu „těleso“ a vyhýbá se slovu ,látka“. V této obežretnosti lze spatřovat ozvěnu dodatečného tvrzení o ,látce pro změnu místa“v vetafyzice VIII,4,1044b6-8: podstaty přírodní, ale věčné nám připomínají, že „některé věci snad nemají žádnou látku, anebo ne takovou, jak ji známe, nýbrž takovou, jež připouští místní pohyb“. Že by nebeská sféra neměla látku, je přitom sotva možné: jak jinak by mohla být nebeská tělesa viditelná? Vážně je však třeba vzít závěr, že tato látka neodpovídá ničemu, s čím máme hmatově založenou smyslovou zkušenost. Nikoli hmatově, ale geometricky založené vyvození prvního tělesa je pak jediným způsobem, jak toto omezení obejít a dospět až k ,jakémusi božskému tělesu“, jemuž schází veškerá teplota i hmatatelná textura. ${ }^{25}$

24 O látce definované místním pohybem viz A. Falcon, Aristotle and the Science of Nature, str. 105-109, a S. Fazzo, Heavenly Matter in Aristotle, Metaphysics Lambda 2, in: Phronesis, 58, 2013, str. 160-175.

25 A. Falcon (Aristotle and the Science of Nature, str. 107) připomíná v této souvislosti Alexandra z Afrodisiady, jehož komentář Metafyziky (In Metaph.22,2-3; 169,18-19; 375,37-376,1) trvá na tom, že nebe je těleso, které nemá látkový substrát v sublunárním slova smyslu. Také v Quaestio 1,10 Alexandros tvrdí, že sublunární a nebeská látka jsou zcela odlišné pojmy. Viz I. M. Bodnár, Alexander of Aphrodisias on Celestial Motions, str. 190-191, pozn. 3. 


\section{Tělesné božstvo}

Výraz ,jakési božské těleso“ je tedy průnikem několika nutností a zároveň omezení. Jeho prvním východiskem je předpokládaná věčnost a dokonalost kruhového pohybu, jenž nutně vyžaduje tělesného nositele. Tento nositel musí být jako pohyblivý plus dokonalý něčím oživeným, ne však pozůstávajícím z látky ve smyslu podloží probíhající změny - není tedy obdobou živočišného těla, které se skládá ze směsi čtyř jednoduchých těles a je utvářeno i oživováno duší. Výsledné první těleso pak může být označeno za božské a být jako současně pohyblivé a božské vyzdviženo - doslova i metaforicky - do postavení v každém ohledu nejlepší části celého světa. Toto vyzdvižení potvrzuje třetí kapitola II. knihy, v níž Aristotelés vysvětluje, proč nemůže být dokonalý kruhový pohyb jediným kosmickým pohybem. Důvodem je nutná nehybnost středu světa, do něhož Aristotelés klade zemi jako jednoduché i fyzikální těleso, jehož nevyhnutelným protikladem je oheň, a spolu s ním i místo potřebné pro pohyb, jímž se od země vzdaluje. A protože země ani oheň nemohou být jako na sebe působící protivy věčně v témže stavu, do schématu světa vstupuje vznik, jímž se vyznačuje celá sublunární sféra. Za povšimnutí přitom stojí, že i tato argumentace vychází z geometrického rozlišení dokonalého kruhového pohybu od pohybů mezi protivami, a teprve poté připisuje různým druhům pohybu př́íslušná fyzikální tělesa. Odtud implikace jdoucí od pohybu opačnými směry $\mathrm{k}$ tělesům nutným pro přirozené uskutečnění pohybu jedním i druhým směrem: bez tohoto zdvojení by sám vznik v sublunární sféře nemohl být přirozený. Pro naše téma je však úžeji relevantní výchozí charakteristika tělesa, které je nutným korelátem pohybu kruhového, tedy tělesa zároveň „božského“ a „kruhového“:

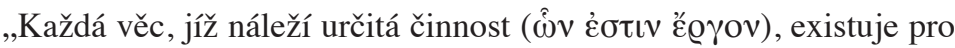

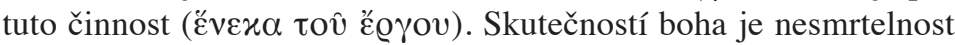

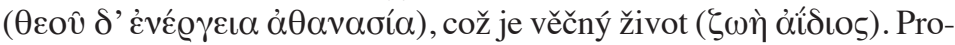

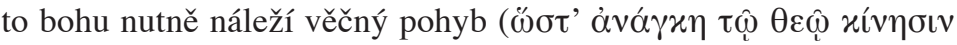

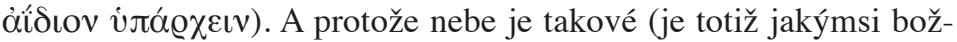

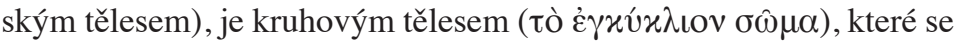
skrze svou přirozenost věčně pohybuje v kruhu. “26

Rámcovou premisu této shrnující pasáže najdeme v různých podobách např́č celým Aristotelovým dílem, od výkladu činnosti tělesných částí

26 Aristotelés, De caelo, II,3,286a8-12. 


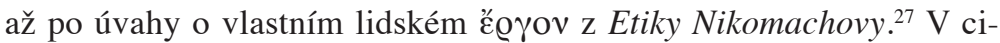
tovaném krajním případě je ovšem schéma existence určité přirozené struktury pro činnost, k níž je určena, zcela prosté: jedinou činností nebeské rotace je sama tato rotace, jež se plně uskutečňuje pohybem prvního tělesa. Tomuto uskutečnění nic neschází; jeho nositel je tedy nejen božský, ale podle řádku $286 \mathrm{a} 10$ je opravdu bohem. Pro řadu interpretů je tento poslední krok problematický prostě proto, že pojem tělesného boha se zdá být v rozporu s bohem Metafyziky XII, jenž je jistě netělesný a kauzálně nadřazený pohybu nebeských sfér. Zda takový rozpor mezi oběma texty skutečně nastává, nebo zda jde o dva zcela různé pohledy na strukturu světa bez původního předpokladu jejich výsledné harmonie, budeme zkoumat později. Nejprve je však třeba zdůraznit, že snaha číst citovanou pasáž tak, abychom z ní vyloučili označení prvního tělesa za boha, nemá v samotném textu dobrou oporu. Sarah Broadiová, která takové čtení hájí, nejprve připomíná, že některé rukopisy nemluví na řádku

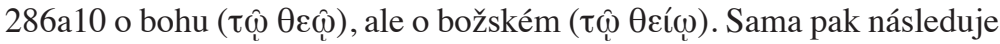
lépe doložené znění $\tau \hat{\omega} \theta \varepsilon \hat{\epsilon}$, ale s dodatkem, že „,na řádku $286 a 10$ je takto označen bůh či božstvo obecně, nikoli nebe, jež se objeví až v dalším kroku argumentace“". ${ }^{28}$ To je jistě pravda, ovšem přechod k tomuto

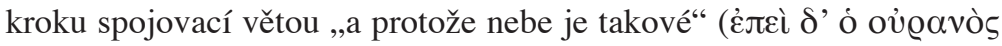

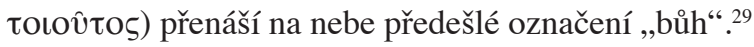

27 Ke každé části těla jako existující ,,pro něco“, vzhledem k čemu vykonává svou činnost, viz De part. animal.I,5,645b14-17. Důraz této pasáže na to,že i celková tělesná stavba má tuto povahu, propojuje biologickou účelnost s etickou otázkou vlastní činnosti

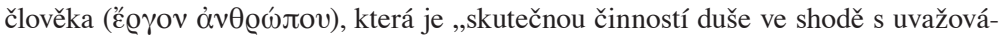
ním anebo nikoli bez uvažování" (Eth. Nic. I,6,1098a7-8). Z diskusí na toto téma viz J. Whiting, Aristotle's Function Argument. A Defense, in: Ancient Philosophy, 8, 1988, str. 49-62; G. Lawrence, The Function of the Function Argument, in: Ancient Philosophy, 21, 2001, str. 445-475; C. M. Korsgaard, Aristotle's Function Argument, in: táž, The Constitution of Agency, Oxford 2008, str. 129-150; J. Jirsa, To ergon tou anthropou, in: Hungarian Philosophical Review, 57, 2013, str. 9-23; S. H. Baker, The Concept of Ergon. Towards an Achievement Interpretation of Aristotle's "Function Argument", in: Oxford Studies in Ancient Philosophy, 48, 2015, str. 227-266.

28 S. Broadie, Corporeal Gods, with Reference to Plato and Aristotle, in: T. Buchheim - D. Meissner - N. Wachsmann (vyd.), $\Sigma \Omega M A$. Körperkonzepte und körperliche Existenz in der antiken Philosophie und Literatur, Hamburg 2016, str. 168, pozn. 18. Broadiová vytváří ve svém textu kontrast mezi Platónem, jenž označuje nebeská tělesa za bohy v dialogu Timaios, a Aristotelem, jenž by zřejmě tělesné božstvo připustit neměl, nebot' - údajně na rozdíl od Platóna - nepokládá nynější tělesný pohyb celku kosmu (jeho rotaci) za zcela soběstačný pohyb.

29 Nic v citovaném textu nenaznačuje, že být „takový“ ( ná být ,jako“ bůh, a nikoli bůh. Naopak některé pasáže Metafyziky XII se zřejmě 
Tento přenos odpovídá tomu, co pojednání $O$ nebi jistě sdílí s Metafyzikou XII, totiž formálně stejný výměr boha skrze nepřetržité oživené uskutečnění (srv. Met. XII,7,1072b27-31). Podstata, která je nositelkou tohoto uskutečnění, je pak v plném slova smyslu božská, at' už díky věčně stejnému kruhovému pohybu, nebo díky věčné činnosti myšlení. Tato podvojnost úplného uskutečnění není nijak problematická, pokud se nesnažíme nastolit mezi dvojí božskou dokonalostí kauzální a současně hierarchický vztah, s jehož nepř́liš rozvedeným náčrtem nás konfrontuje Metafyzika XII. Není přitom pochyb o tom, že Metafyzika promítá do stavby světa hodnotové hledisko ještě silněji, než tak činí pojednání $O$ nebi. Otázka, zda nakonec i toto pojednání předpokládá motiv netělesného hybatele kosmické rotace, je tak klíčová pro případné rozhodnutí, zda oba texty tvoří jasně hierarchický celek, nebo zda představují dvojí zcela odlišný a stejně originální - pohled na dokonalost (či nikoli) fyzikálního světa jako celku. Druhá část této studie se proto obrátí k třem pasážím spisu $O$ nebi, jež bývají uváděny na podporu ústřední role prvního nehybného hybatele ve všech verzích aristotelské kosmologie. Na základě jejich interpretace, provázené závěrečným, nutně stručným srovnáním s několika pasážemi Metafyziky, vyvstanou přednosti i nevýhody obojího čtení. ${ }^{30}$

\section{ZUSAMMENFASSUNG}

In De caelo I-II ersetzt Aristoteles die platonische Weltseele mit einem sich selbst bewegenden, innerlich beseelten „ersten Körper“. Der Artikel rekonstruiert Aristoteles' schrittweise Vorstellung von diesem nicht nur geometrisch, sondern auch materiell vollkommenen Körper und zwar mit einem besonderen Augenmerk auf seine innere Beseelung. Das letzte ergibt sich aus denselben Prinzipien der beseelten Bewegung, denen wir in den biologischen Abhandlungen begegnen. Dennoch bestreitet Aris-

blíží případu, kdy jsou jako „,božské“ popsány bytosti, které nechceme označit přímo za „,boha“. Otázkou je, zda by tento rozdíl platil i pro to, co je „,nejbožštějšíi“ ( $\theta \varepsilon$ เó $\alpha \tau o v)$. Je-li totiž „,nejbožššěš̌í “ jen třetím stupněm „božského“, která konkrétní podstata by prostě byla bohem? Připomeňme, že za „nejbožštější“ označuje $M e$ -

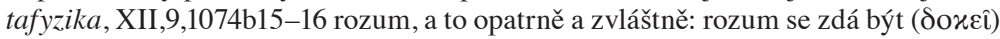

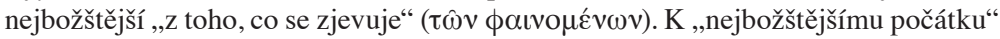

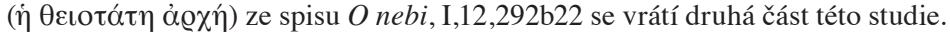

30 Tato práce vznikla za podpory projektu Kreativita a adaptabilita jako předpoklad úspěchu Evropy v propojeném světě reg. č.: CZ.02.1.01/0.0/0.0/16_019/0000734 financovaného z Evropského fondu pro regionální rozvoj. 
toteles, dass der erste Körper oder einfach die Himmelsphäre eine Seele von der Art hat, wie sie in De anima vorgestellt ist. Der Artikel untersucht näher die verschiedenen konzeptionellen Folgen dieser Bestreitung, einschließlich der Notwendigkeit, das Insistieren auf der körperlichen Natur der Himmel in Einklang zu bringen mit der Voraussetzung einer sich selbst genügenden Vollkommenheit. Zu diesem Zweck - so das Ergebnis meines Artikels nach einer detaillierten Untersuchung von einigen Passagen einschließlich De caelo, II,3,286a8-12 - rekurriert Aristoteles auf seine allgemeine Vorstellung Gottes als einer ewigen, unveränderlichen und beseelten Aktualität: sicherlich, nichts hindert Aristoteles daran, diesen Gottesbegriff auf die geometrisch und körperlich vollkommene Substanz anzuwenden, obwohl dies eine Frage aufwirft (die im nachfolgenden, zweiten Teil des Artikels entfaltet wird), wie man die gänzlich naturhafte Vollkommenheit mit dem Begriff des unkörperlichen ersten Bewegers in Einklang bringen soll, einem Begriff, der anscheinend in De caelo selbst nebenher eingeführt wird.

\section{SUMMARY}

In De caelo I-II, Aristotle replaces the Platonic world soul with a self-moving, internally animate "first body". The article reconstructs Aristotle's progressive introduction of this not only geometrically, but also physically perfect body, with a special focus on its internal animation. The latter follows from the same principles of animate motion that we encounter in the biological treatises, yet Aristotle denies that the first body or simply the celestial sphere has a soul of the kind that he introduces in De anima. The article takes a closer look at various conceptual implications of this denial, including the need to reconcile the insistence on the corporeal nature of the heavens with the premise of its self-sustaining perfection. It is to this end, the article concludes after a detailed examination of several passages including De caelo, II,3,286a8-12, that Aristotle recurs to his general notion of god as eternal, changeless and animate actuality: clearly, nothing prevents Aristotle for applying this notion of god to a geometrically and physically perfect substance, although this move raises the question (developed in this article's forthcoming second part) of how to reconcile this fully natural perfection with the notion of the incorporeal prime mover, a notion apparently sidelined in De caelo itself. 